University of Nebraska - Lincoln

DigitalCommons@University of Nebraska - Lincoln

Carbon Dioxide Dynamics During a Growing Season in Midwestern Cropping Systems

\author{
J. H. Prueger \\ USDA-ARS \\ J. L. Hatfield \\ USDA-ARS, jerry.hatfield@ars.usda.gov \\ T. B. Parkin \\ USDA-ARS \\ W.P. Kustas \\ USDA-ARS
}

T. C. Kaspar

Follow this and additional works at: https://digitalcommons.unl.edu/usdaarsfacpub

Part of the Agricultural Science Commons

Prueger, J. H.; Hatfield, J. L.; Parkin, T. B.; Kustas, W.P.; and Kaspar, T. C., "Carbon Dioxide Dynamics During a Growing Season in Midwestern Cropping Systems" (2004). Publications from USDA-ARS / UNL Faculty. 251.

https://digitalcommons.unl.edu/usdaarsfacpub/251

This Article is brought to you for free and open access by the U.S. Department of Agriculture: Agricultural Research Service, Lincoln, Nebraska at DigitalCommons@University of Nebraska - Lincoln. It has been accepted for inclusion in Publications from USDA-ARS / UNL Faculty by an authorized administrator of DigitalCommons@University of Nebraska - Lincoln. 


\section{Carbon Dioxide Dynamics During a Growing Season in Midwestern Cropping Systems}

\author{
J. H. PRUEGER \\ J. L. HATFIELD \\ T. B. PARKIN \\ USDA/ARS National Soil Tilth Laboratory \\ Ames, lowa, USA

\section{W. P. KUSTAS} \\ USDAVARS Hydrology and Remote Sensing Laboratory \\ Beltsville, Maryland, USA
}

\section{T. C. KASPAR}

USDAVARS National Soil Tilth Laboratory

Ames, lowa, USA

ABSTRACT / Daily and seasonal $\mathrm{CO}_{2}$-exchange dynamics between the boundary layer and biosphere is important to understanding Net Ecosystem Exchange of terrestrial ecosystems. Spatial and temporal variations of $\mathrm{CO}_{2}$ fluxes across midwestern cropping systems have not been well documented. This study was designed to monitor and evaluate spatial and temporal dynamics of $\mathrm{CO}_{2}$ exchange across a watershed region for typical production fields of corn (Zea mays L.) and soybean [Glycine max (L.) Merr.] in the Midwest by quantifying the above-canopy, within-canopy, and soil components of $\mathrm{C}$ balance for this cropping system. An energy- balance approach using eddy covariance was utilized across different fields making year-around measurements in both corn and soybean fields to quantify the exchange of $\mathrm{CO}_{2}$ and $\mathrm{H}_{2} \mathrm{O}$ between the crop canopy and the atmospheric boundary layer. Within-canopy concentrations of $\mathrm{CO}_{2}$ and $\mathrm{H}_{2} \mathrm{O}$ vapor were measured with an eight-port $\mathrm{CO}_{2} / \mathrm{H}_{2} \mathrm{O}$ infrared analyzer. Soil respiration was quantified using soil chambers at various landscape positions throughout the growing season. Fluxes of $\mathrm{CO}_{2}$ and $\mathrm{H}_{2} \mathrm{O}$ vapor throughout the day were dependent on net radiation and the stage of canopy development. Diurnal variations in $\mathrm{CO}_{2}$ and $\mathrm{H}_{2} \mathrm{O}$ vapor fluxes revealed that the magnitude of the fluxes is large and the variation of the fluxes among fields was consistent throughout the season. Integration of the daily fluxes into seasonal totals showed large differences among crops and fields. Flux differences were the result of the effect of varying soil types on water-holding capacity. Seasonal integrated values were lower than estimates derived from biomass samples collected within the fields and the measurement of the $\mathrm{C}$ content of the biomass. Within-canopy recycling of soil $\mathrm{CO}_{2}$ may provide insight to this discrepancy. The techniques are available to quantify the $\mathrm{CO}_{2}$ and $\mathrm{H}_{2} \mathrm{O}$ vapor fluxes across different management systems and landscapes to help refine our understanding of the magnitude of the $\mathrm{CO}_{2}$ and $\mathrm{H}_{2} \mathrm{O}$ dynamics in cropping systems.
Interest in changes of atmospheric concentrations of carbon dioxide $\left(\mathrm{CO}_{2}\right)$ and the potential impacts on global climate change continues to grow. The diversity of soil, vegetative landscapes, and microclimate on Earth represents an important need to understanding the dynamics of terrestrial $\mathrm{CO}_{2}$ uptake by elements of the biosphere and subsequent carbon (C) sequestration. In particular, anthropogenic impacts in the form of modern agricultural practices imposed on regional scales of land surfaces present new challenges to understanding carbon-exchange dynamics. Houghton (1999) estimated $124 \mathrm{Pg} \mathrm{C}$ (petagrams-10 ${ }^{15} \mathrm{~g}$ ) have been added to the atmosphere as a result of land-use changes between the years 1850 and 1990. Of the 124 Pg C, 108 Pg C has been transferred from forests to the

KEY WORDS: Carbon dioxide; Eddy covariance; Soil respiration; Energy balance

Published online

Published online March 23, 2004. atmosphere within the tropics and in the temperate regions. The remaining $16 \mathrm{Pg} \mathrm{C}$ is estimated to be from the conversion of midlatitude grasslands to modern agricultural production regions. Houghton (1999) further estimated that globally for the 140-year interval, over 800 million hectares of forest have been cleared for agricultural purposes. This is in addition to nearly 2 billion hectares of harvested forests. On the basis of these estimates, it can be safely stated that the impact of the human component of land-use changes is significant.

Past and current $\mathrm{CO}_{2}$ monitoring efforts have been heavily weighted toward the marine boundary layer and the land biosphere has been underrepresented (Inoue and Matsueda 2001). Given the vast diversity and complexity of the terrestrial biosphere and coupled with relatively scarce sources of measured data, it is not altogether surprising that the role of terrestrial ecosystems is uncertain. For example, Houghton and Hackler (1995) estimated that in the 1980's global terrestrial 
systems represented a source of $\mathrm{C}$ to the atmosphere of about 1.6 Pg C year, whereas Tans and others (1990), Keeling and others (1995), and Rayner and others (1999) reported that the terrestrial eco-systems represented a sink in the range of 2-3.4 Pg C year. Understanding the complex interactions between the atmosphere and any terrestrial ecosystem requires careful and accurate measurements of all potential sources and sinks $\mathrm{CO}_{2}$ relevant to the system under study. Equally important is the need for long-term monitoring of $\mathrm{CO}_{2}$-exchange processes, as different ecosystems exhibit significant seasonal, annual, and decadal variability.

In this article, we focus on fundamental $\mathrm{CO}_{2}$-exchange dynamics for a corn and soybean production system that is representative of the Upper Midwest corn-soybean region of the United States. This is an agricultural region comprised of over 60 million hectares representing $60 \%$ of the US cropland and is a large-scale example of a significant midlatitude landuse conversion (native prairie grass to corn-soybean). The potential for impacting $\mathrm{C}$ management as a function of production techniques is promising. In agricultural cropland systems, there are a number of biophysical factors that affect $\mathrm{CO}_{2}$ exchange. These include biotic (plant and soil) and abiotic (light, water, turbulence) factors associated with soil, plant, and atmospheric properties (McNaughton 1989; Buchmann and others 1996, Buchmann and others 1997). Adequately characterizing sources, sinks, and transport processes requires reliable measurements of the soil-vegetationatmosphere continuum. Measurement techniques can include chamber (soil and plant respiration), profile concentrations (above and below canopy), and eddy covariance for Net Ecosystem Exchange (NEE) estimates above a vegetated surface.

In production agricultural systems, it is well known that $\mathrm{CO}_{2}$ concentration values below a dense canopy can be subtropospheric $(<360 \mathrm{ppm})$ during active $\mathrm{CO}_{2}$ uptake periods (daylight) and significantly above mean tropospheric values $(\sim 360 \mathrm{ppm})$ prior to sunrise (nighttime) (Lemon 1960; Keeling 1961; Wright and Lemon 1966; Allen 1971; Reicosky 1989; Buchmann and others 1996). Below-canopy $\mathrm{CO}_{2}$ profiles are strongly affected by crop leaf area index (LAI) and foliage density [e.g., Lemon and Wright (1969) ]. Nighttime enrichment of the below-canopy airspace results from soil and vegetative respiration processes. In a dense crop such as corn and under low-wind-speed conditions, turbulent mixing is limited due to increased boundary layer resistance (Baldocchi and others 1981). From past studies, the role that soil respiration plays in canopy $\mathrm{CO}_{2}$-exchange dynamics is not clear; nor have the linkages among soil, canopy, and boundary layer $\mathrm{CO}_{2}$-exchange dynamics and system carbon budgets been established. Detailed measurements of sources and sinks of $\mathrm{CO}_{2}$ in a corn-soybean production system in the Upper Midwest region are limited in space and time and are needed to better understand the dynamics of $\mathrm{CO}_{2}$ exchange for a major agricultural ecosystem. The objectives of this study were to quantify daily and seasonal $\mathrm{CO}_{2}$ and $\mathrm{H}_{2} \mathrm{O}$ vapor exchange from soil, within and above corn-soybean canopies across multiple production fields in a typical agricultural production ecosystem of the Upper Midwest region.

\section{Materials and Methods}

\section{Site Description}

The study was conducted in the Walnut Creek Watershed (WCW) in central Iowa located $5 \mathrm{~km}$ south of Ames, Iowa $\left(41^{\circ} 75^{\prime} \mathrm{N}, 93^{\circ} 41^{\prime} \mathrm{W}\right)$ as part of an ongoing monitoring effort. It is a 5100-ha watershed (Figure 1) of privately owned production fields that are representative of the Upper Midwest region. This is part of a larger research study to assess interactions of crop water use, growth, and yield as a function of nitrogen management. Typical field sizes can range from 80 to 160 ha. The topography of the WCW is in general characterized by flat to gently rolling terrain. Elevations in the watershed range from 265 to $363 \mathrm{~m}$, with the lowest elevations found on the eastern end of the watershed, where the Walnut Creek drains. Corn and soybean production tillage and nutrient management systems within the watershed are described in Hatfield and others (1999). The watershed has approximately equal planted areas of corn and soybeans. Two fields were selected for long-term $\mathrm{CO}_{2} / \mathrm{H}_{2} \mathrm{O}$ turbulent flux monitoring. Both fields alternate as corn and soybean fields and were first instrumented in 1999 and continue through the present. Monitoring continues during the nonproduction season as well as the active growth period. Instrumented towers are removed for a short period (1-7 days) for harvest and planting operations in the fall and spring, respectively. An intensive field study involving multiple towers and fields across the WCW was conducted in the summer of 2002 as part of the Soil Moisture Experiment 2002 (SMEX02). The long-term continuous monitoring study will be used to evaluate net primary production (NPP) for corn and soybeans, whereas the intensive study (SMEX02) will be used to focus on net ecosystem exchange (NEE) as a function of spatial and temporal variability across the watershed. This article focuses on preliminary results found in the SMEX02 portion of the study. 


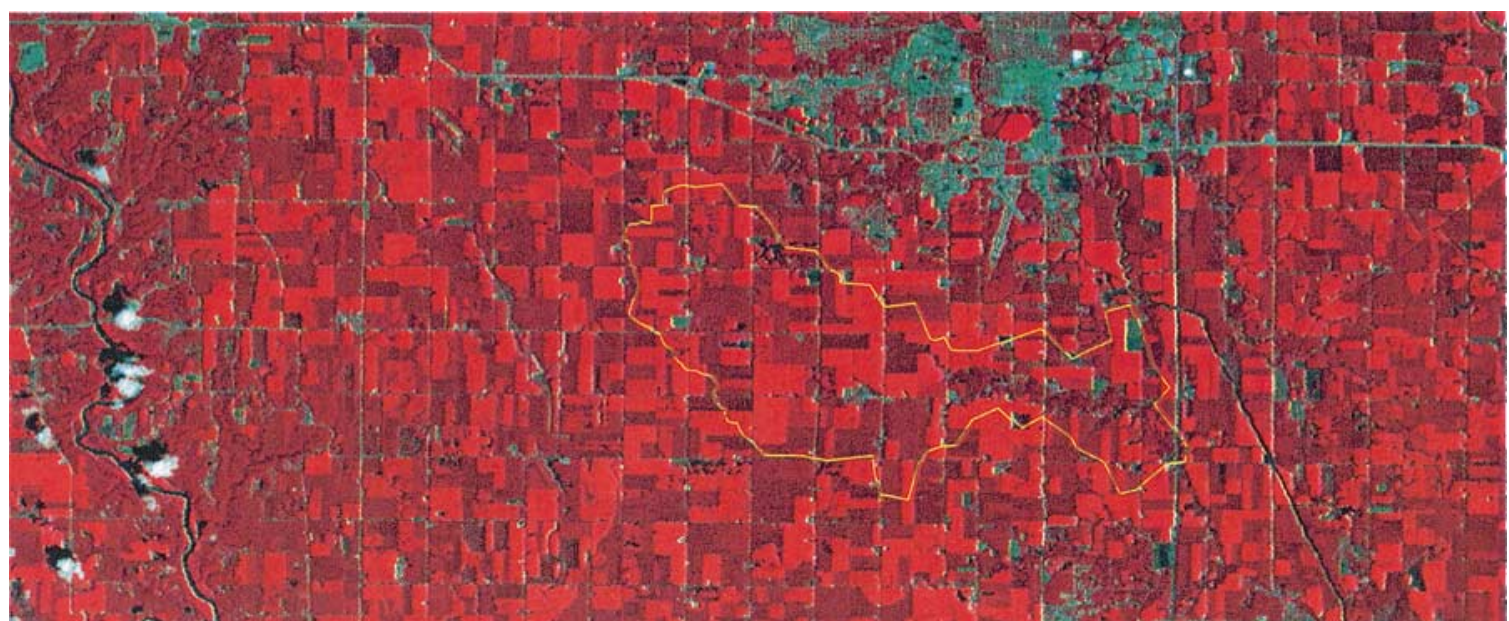

Figure 1. Land Sat image of central Iowa near Ames with outline of Walnut Creek Watershed.

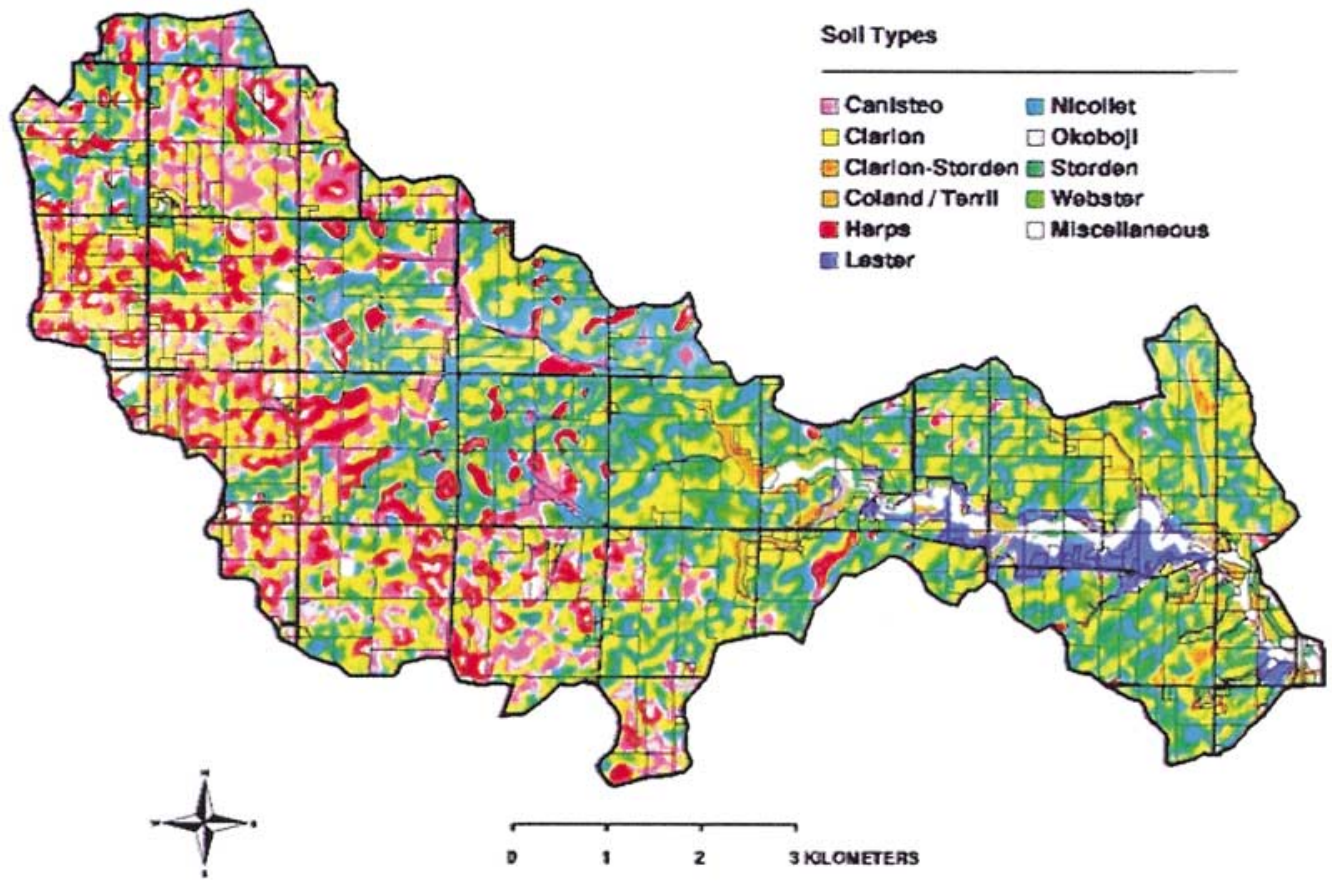

Figure 2. Soil types within the Walnut Creek Watershed, Iowa.

\section{Soils}

The WCW has approximately 10 major soil types (Figure 2), with Nicollet, Clarion and Canisteo soils comprising the dominant series of soil types in the watershed. These are generally silt loam soils [fineloamy, mixed (calcareous), mesic Typic or Aquic Haplaquolls]. Canisteo soils are poorly drained calcareous soils and are found mostly in the north and west portions of the watershed. Nicollet soils are also poorly drained and are located mainly in swales and knolls and represent nearly $2 / 3$ of the watershed. Clarion soils are well drained, occur on the higher-sloped areas, and, thus, are more uniformly distributed throughout the watershed. Large depression areas (potholes) ranging in diameter from tens to hundreds of meters across are found in many of the fields. The potholes are mostly comprised of Nicollet and Okoboji soils, which are poorly drained and thus often serve as local catchments for surface runoff following heavy precipitation events; consequently, many of the fields are underlain with tile 
drains to hasten excess soil water drainage. The presence of a tile drainage system can affect the available soil water content across a landscape surface that will contribute to local spatial variations in water, heat, and carbon dioxide exchanges. Earlier studies by Hatfield and Prueger (2001) have shown large variations in water use across a production cornfield. A site was selected in a corn production field on a Canisteo silt loam soil. The watershed area has approximately equal planted areas of corn and soybeans.

\section{Instrumentation-Eddy Covariance-Ancillary}

Turbulent fluxes of latent heat (LE) and $\mathrm{CO}_{2}$ were measured using an eddy covariance (EC) approach. The instrumentation consists of a three-dimensional sonic anemometer (CSAT3; Campbell Scientific Inc. Logan, Utah, USA) and a fast-response water vapor $\left(\mathrm{H}_{2} \mathrm{O}\right)$ and $\mathrm{CO}_{2}$ density open-path infrared gas analyzer (IRGA) (LI7500; LiCor Inc., Lincoln, Nebraska, USA). The EC instruments were mounted on 10-m towers at $3 \mathrm{~m}$ above the ground surface (AGL). Ancillary instrumentation on each tower site included a net radiometer $\left(R_{n}\right)\left(Q^{*} 7.1\right.$ Radiation Energy Balance Systems; REBS, Seattle, Washington, USA), soil heat flux plates (G) (REBS HFT-3) Cu-Co Type $\mathrm{T}$ soil thermocouples, a high-precision infrared radiometric temperature sensor (IRT $15^{\circ}$ fov) (Apogee, Logan, Utah, USA), and an air temperature $\left(\mathrm{T}_{\mathrm{a}}\right)$ and relative humidity $(\mathrm{RH})$ sensor (Vaisala HMP-35; Campbell Scientific Inc. Logan, Utah, USA). The $\mathrm{R}_{\mathrm{n}}$ and IRT sensors were mounted $4.5 \mathrm{~m}$ above AGL. Two soil heat flux plates buried at $0.06 \mathrm{~m}$ below the soil: one within the plant row and the second in the interrow space. Soil thermocouples were placed at 0.02 and $0.04 \mathrm{~m}$ below the surface and above each soil heat flux plate to compute the storage component of the soil heat flux. Soil water content was measured with Delta-T Theta Probes (Dynamax Houston, Texas, USA).

As part of the long-term objectives within WCW, we have established two complete EC towers (1999present) as described earlier within a corn and soybean field after planting and pesticide application. Corn and soybean heights were monitored throughout each growing season. Instrument heights were periodically incremented to maintain instrument height at a constant height $(3 \mathrm{~m})$ above the developing canopy.

In 2002, a remote sensing soil moisture experiment (SMEX02) was conducted in the WCW. This study provided the opportunity to place an additional 12 EC stations to evaluate the spatial variation among fluxes across a range of fields within the watershed. These stations were in operation during the intensive measurement period of the remote sensing campaign (Kus- tas and others 2003) and remained so until late August 2002. This served as an excellent opportunity to not only measure and evaluate differences in turbulent fluxes between corn and soybeans but also the spatial and temporal variability of turbulent flux exchange of $\mathrm{CO}_{2}$ and $\mathrm{H}_{2} \mathrm{O}$ across the WCW landscape. The tower and instrument configurations of the additional EC towers were similar to the two long-term towers.

Data collected from these towers were screened for data outliers for all of the parameters. This was accomplished by plotting the data for trends within a day and by examining the calculated fluxes from the different parameters and plotting the temporal changes in the flux values. This process was completed for each tower, and if any data points were suspect, the entire time period was deleted from the record. Data capture for this experiment was greater than $95 \%$ during the summer of 2002.

\section{Corn Canopy $\mathrm{CO}_{2} / \mathrm{H}_{2} \mathrm{O}$ Profile Measurements}

In one cornfield, canopy profile measurements of $\mathrm{CO}_{2} / \mathrm{H}_{2} \mathrm{O}$ vapor density were conducted with a closedpath IRGA (LI6262, LiCor; Lincoln, Nebraska, USA); five within the canopy at $0.15,0.27,0.50,0.91$, and $1.65 \mathrm{~m}$ AGL and one above $(3 \mathrm{~m})$. The sampling frequency was $10 \mathrm{~Hz}$, with data output as 30-min averages. These measurements were used to evaluate canopy space $\mathrm{CO}_{2} / \mathrm{H}_{2} \mathrm{O}$ density dynamics as a function of time and turbulent energy exchange above the canopy. No profile measurements were made for the soybeans.

\section{Chamber-Based Soil $\mathrm{CO}_{2}$ Flux Measurements}

At three locations in a cornfield in the WCW, pairs of automated $\mathrm{CO}_{2}$ flux chambers, similar in design to those of Ambus and Robertson (1998), were installed. The chambers were $0.30 \times 0.30 \times 0.30$-m tall, stainlesssteel, open-ended boxes pressed into the soil $\sim 0.05 \mathrm{~m}$. The top of each steel box was fit with a wooden framework that supported a sliding cover. The covers were supported by casters riding on steel tracks attached to the sides of the chambers. Carbon dioxide fluxes were measured every hour from 19 June 2002 (DOY 170; day of year) through 1 August 2002 (DOY 213) by sliding the cover over the chamber top to close the chamber and allow $\mathrm{CO}_{2}$ to accumulate in the chamber headspace. Carbon dioxide was measured during a 360-s period by pumping the chamber headspace gas through an infrared gas analyzer (IRGA) (LI-800 GasHound; LiCor, Lincoln, Nebraska, USA) and out to the atmosphere. The gas flow rate through the chambers was $0.0108 \mathrm{~L} / \mathrm{s}$. A vent port in each chamber allowed pressure equilibration within the chambers. 
Headspace $\mathrm{CO}_{2}$ concentrations were determined at 1-min intervals in each chamber, and after $6 \mathrm{~min}$, the chambers were reopened. A small fan was located in each chamber to mix the air $(6.7 \mathrm{~L} / \mathrm{s})$ during the $\mathrm{CO}_{2}$ flux measurements. Headspace $\mathrm{CO}_{2}$ concentrations were typically curvilinear with time, indicating that $\mathrm{CO}_{2}$ flux was limited by a reduction in the diffusion rate caused by increasing headspace $\mathrm{CO}_{2}$ concentrations while the chambers were closed. We corrected for this effect using the algorithm of Hutchinson and Mosier (1981). Because the chambers were operating in an open-system mode (headspace gas from the vented chambers was pumped through the IRGA and out to the atmosphere), corrections were made for the mass of $\mathrm{CO}_{2}$ entering the chamber from the vent port as well as the mass of $\mathrm{CO}_{2}$ removed from the chamber by the IRGA pump. Initial $\mathrm{CO}_{2}$ concentrations were determined from an ambient $\mathrm{CO}_{2}$ concentration measurement obtained immediately before the chambers were closed. Due to the low gas pump rate $(0.0108 \mathrm{~L} / \mathrm{s})$ relative to the chamber headspace volume $(\sim 22.5 \mathrm{~L})$, these corrections were typically within $1 \%$ of the measured headspace $\mathrm{CO}_{2}$ concentration at each time point. Each chamber was instrumented with Type-T (Cu-Co) thermocouples to measure air and soil temperature, and the chamber was closed for $\mathrm{CO}_{2}$ flux measurements. Soil temperature in each chamber was measured with four thermocouples: two placed less than $0.01 \mathrm{~m}$ below the soil surface and two placed $0.05 \mathrm{~m}$ below the soil surface. The air temperature in each chamber was also measured with two thermocouples suspended $\sim 8 \mathrm{~cm}$ above the soil surface. Soil water content in each chamber was monitored with Delta-T Theta Probes (Dynamax, Houston, Texas, USA). Two soil water content probes were installed in the surface soil (0.01-0.06 m) of each chamber. Soil water content probes were calibrated at each site and the slight temperature effect on probe response $\left(\sim 0.005 \mathrm{~kg} / \mathrm{kg} /{ }^{\circ} \mathrm{C}\right)$ was corrected using an empirically derived equation. Temperature and soil water content measurements were made at hourly intervals during the time when the chambers were closed, and average values during each hourly $\mathrm{CO}_{2}$ flux measurement period are reported. Two 12-V deep-cycle batteries, connected in parallel and supplemented with solar cells, provided power to each station. Each site was also instrumented with a data logger (CR21X; Campbell Scientific, Logan, Utah, USA) that controlled the chamber automation and collected the hourly data. Midway through the measurement period (DOY 186), one of the chambers at one location failed; thus, data presented are means and associated statistics of the five remaining chambers.

\section{Results}

Data collected during the 2002 growing season revealed several characteristics about $\mathrm{CO}_{2}$ dynamics above, within, and at the soil surface. Past analysis have focused on the ambient exchange rates coupled with canopy biomass measurements. We present data beginning with ambient concentrations and extending down through the canopy to the soil surface. This approach allows for a more thorough examination of the components of $\mathrm{C}$ exchanges for a cornfield.

\section{Ambient $\mathrm{CO}_{2}$ Concentrations}

Current mean global atmospheric $\mathrm{CO}_{2}$ concentrations varied between 360 and 370 parts per million (ppm) (Kasting 1993; Berner 1997). Daily ambient concentrations of $\mathrm{CO}_{2}$ in the WCW during the growing season were found to be strongly diurnal with pre dawn values of over $500 \mathrm{ppm}$ to midday values of around 300 ppm or less. Results for 1 day (16 July 2002) over a corn and soybean field showed a typical diurnal trend for a clear warm day in Iowa of $\mathrm{CO}_{2}$ fluxes (Figure 3a). Peak concentrations generally occurred around $0300 \mathrm{~h}$ Central Standard Time (CST), with the higher concentrations found over corn relative to soybeans $(\sim 515$ versus $475 \mathrm{ppm})$. Carbon dioxide concentrations were observed to rapidly decrease shortly after sunrise (0600 CST) and reach near-constant values (300 ppm) at about the same time as the light saturation point (0900 CST) and remain so for the duration of the daylight period. Extending the temporal sequence for 9 days (16-24 July 2002) showed expected trends of $\mathrm{CO}_{2}$ concentrations for a cornfield (Figure 3b). Distinct diurnal oscillations of ambient $\mathrm{CO}_{2}$ concentrations were readily observed near the surface with considerable variability for peak concentrations during nighttime hours and relatively constant lower $\mathrm{CO}_{2}$ concentrations during the daytime hours. Computing mean daily ambient concentrations of $\mathrm{CO}_{2}$ from both corn and soybean fields for the growing period from June through August showed that for the WCW, there are number of days that the mean ambient $\mathrm{CO}_{2}$ concentration values were considerably lower than the mean ambient global concentration (Figure 3c).

\section{Diurnal Fluxes of $\mathrm{CO}_{2}$ and $\mathrm{H}_{2} \mathrm{O}$ Vapor over Corn and Soybean Canopies}

Turbulent flux measurements of $\mathrm{CO}_{2}$ and $\mathrm{H}_{2} \mathrm{O}$ made with the EC systems provide temporal and spatial details that are not always possible with other measurement systems. In this study, we aggregated the data into 30 -min averages for comparison purposes. Figure 4 shows typical results of three daily 30-min average $\mathrm{CO}_{2}$ 

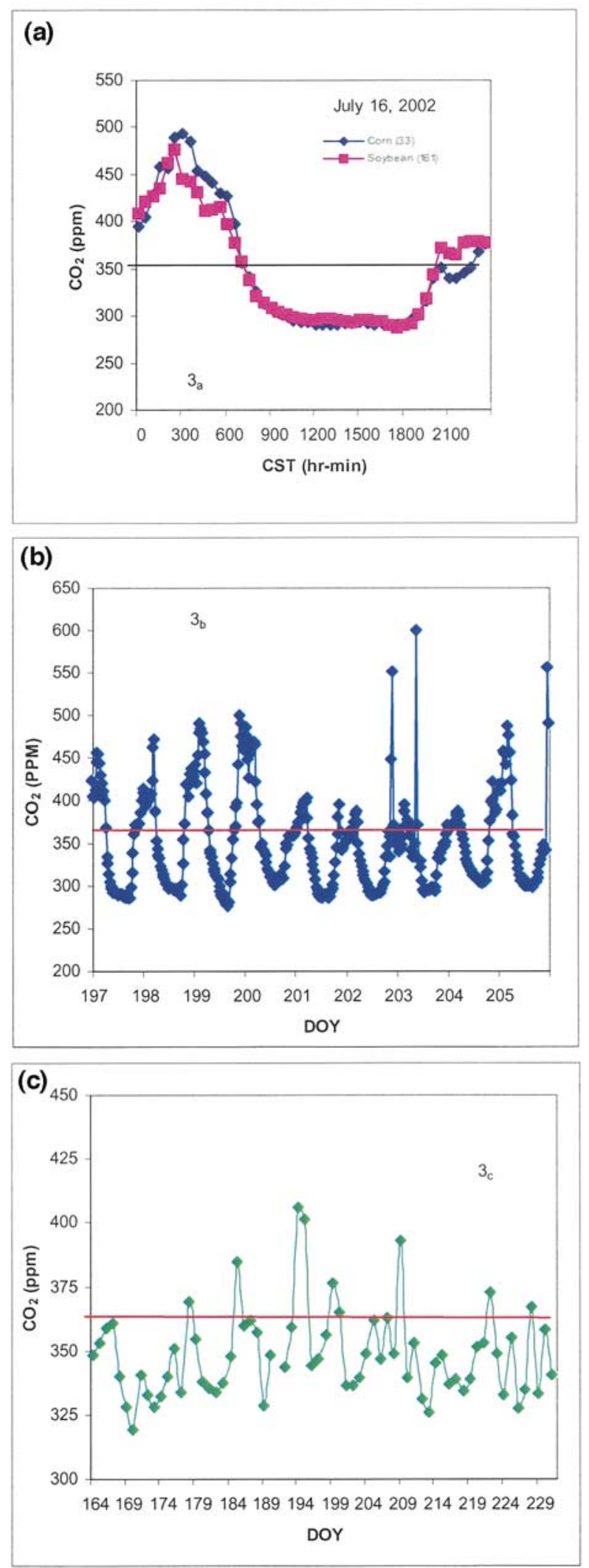

flux estimates over corn from three distinct periods during the growing season (16 June, 17 July, and 17 August 2002). On 16 June 2002, the mean corn height was $\sim 0.5 \mathrm{~m}$ and had daytime peak $\mathrm{CO}_{2}$ flux values of $\sim 0.75 \mathrm{mg} / \mathrm{m}^{2} / \mathrm{s}$. The results from 17 July 2002 represented the tassel period and corresponded to the maximum corn canopy height $(\sim 2.7 \mathrm{~m})$. During this period, $\mathrm{CO}_{2}$ fluxes exceeded $2.5 \mathrm{mg} / \mathrm{m}^{2} / \mathrm{s}$, the maximum $\mathrm{CO}_{2}$ uptake. Later in August, the corn canopy height was reduced due to tassel senescence/removal as well as leaf senescence began to occur in the lower canopy. $\mathrm{CO}_{2}$ flux values had begun to decrease for the season but still exceeded $2 \mathrm{mg} / \mathrm{m}^{2} / \mathrm{s}$.

Another feature to note are the abrupt and shortterm decreases in flux rates that were related to afternoon overpasses of cumulus clouds that developed during mid-day and late-afternoon periods. Positive $\mathrm{CO}_{2}$ fluxes (away from the surface) were also readily observed during nighttime periods, representing a net transport of $\mathrm{CO}_{2}$ away from the canopy surface. It is reasonable to conclude that the surface acts as a temporary source to the atmosphere and that respiration processes (soil and plant) enrich the canopy airspace with $\mathrm{CO}_{2}$ and contribute to the net $\mathrm{CO}_{2}$ flux to the atmosphere. Figure $4 \mathrm{~b}$ show similar results for soybeans. Notable differences include lower magnitude of the fluxes relative to corn and nearly the same flux rates for July and August. A significant drop in $\mathrm{CO}_{2}$ flux was observed for August and was related to a single large cloud passage that was centered over the soybean field and only marginally covered the corn site.

Daily turbulent fluxes of water vapor for the corn and soybeans are presented in Figures $4 \mathrm{c}$ and $4 \mathrm{~d}$, respectively. Early in the season (16 June), evapotranspiration (ET) fluxes for corn were nearly double those for the soybeans, as during this period, corn vegetative development was nearly triple that of the soybeans. After full canopy development had been achieved in both corn and soybeans (17 July), ET fluxes became comparable but were slightly larger for corn. The same trend continued through 17 August; note the similar response of ET during the mid-day cloud passage as observed for the $\mathrm{CO}_{2}$ flux (Figures 4a and 4d) Figures $4 a-4 d$ further illustrate the dynamic nature of turbulent exchange processes between the surface and the

$\overline{\text { Figure 3. (a) Diurnal ambient } \mathrm{CO}_{2} \text { concentrations on } 16 \mathrm{July}}$ 2002 over a corn and soybean field. (b) Ambient $\mathrm{CO}_{2}$ concentrations for 9 consecutive days over a cornfield in the Walnut Creek Watershed. (c) Mean ambient $\mathrm{CO}_{2}$ concentration for the 2002 growing season for a cornfield in the Walnut Creek Watershed. 

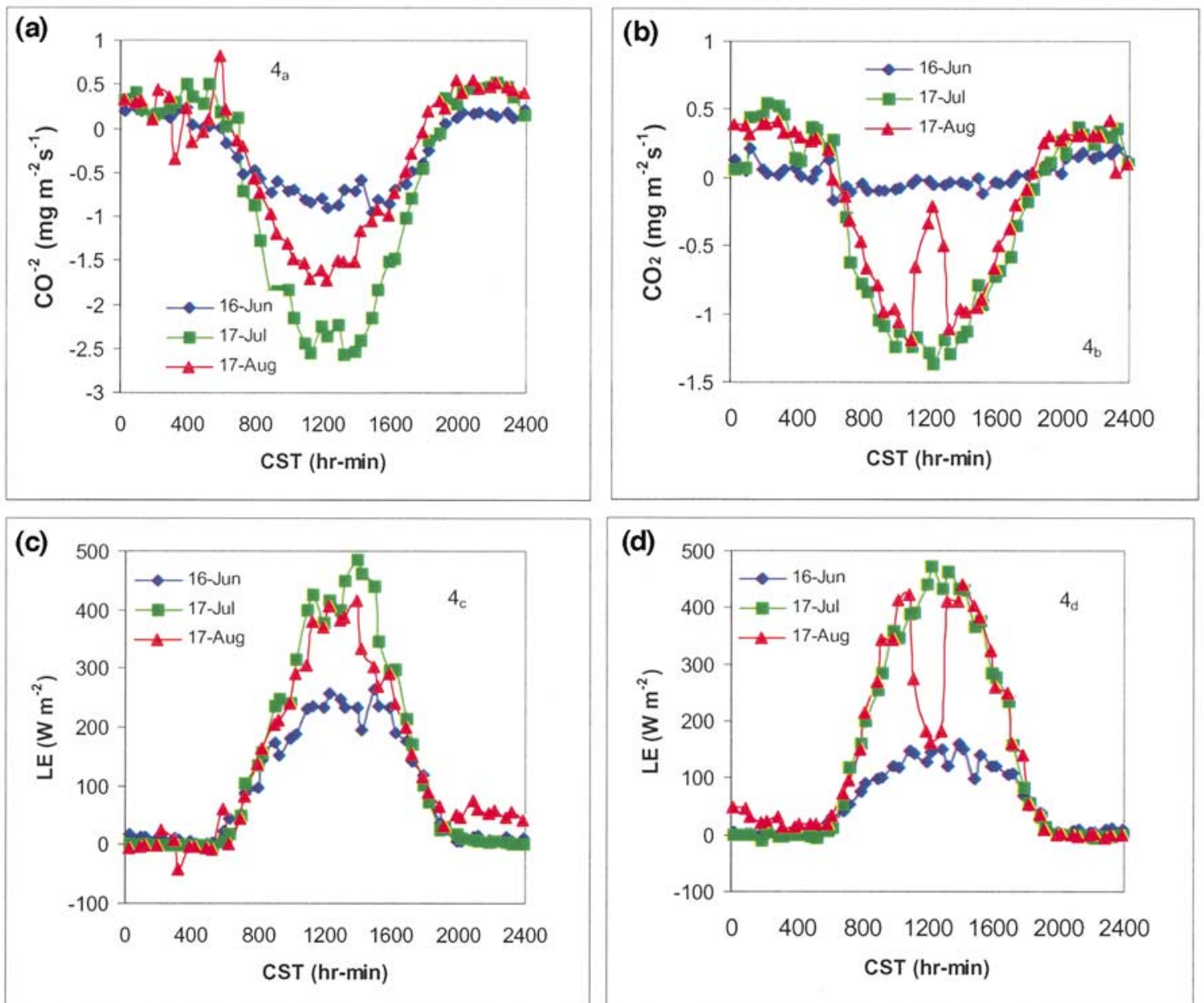

Figure 4. Thirty-minute $\mathrm{CO}_{2}$ flux average for corn (a) and soybean (b) for 3 days in the growing season (16 June, 17 July, and 17 August, 2002) and 30-min (LE)flux averages for corn (c) and soybean (d) for 3 days in the growing season (16 June, 17 July, and 17 August 17 2002).

overlying atmosphere. Variability can be observed both spatially and temporally, and the temporal variation has both a diurnal and seasonal component.

To examine the spatial variation of the fluxes, we aggregated the data across several systems that were placed throughout the watershed. The range of $\mathrm{CO}_{2}$ fluxes on 16 July 2002 shows a large variation in the fluxes, and the standard error about the mean was large for both corn and soybeans (Figures $5 \mathrm{a}$ and $5 \mathrm{c}$ ). These systems were placed in similar landscape positions within the watershed and would represent the typical level of variation found for $\mathrm{CO}_{2}$ and $\mathrm{H}_{2} \mathrm{O}$ fluxes across a large agricultural area (Figures 5a-5d). The cornfields at this time were near the maximum LAI and soybean fields had achieved complete ground cover with LAIs above 4 . Water vapor fluxes for this same day showed similar standard errors about the mean for both crops (Figures $5 \mathrm{~b}$ and $5 \mathrm{~d}$ ). The magnitude of the standard error was typical of what was observed during this experiment and suggested that mean values over large agricultural regions should include an estimate of the variation. The variation observed in this study of a relatively homogeneous agricultural region suggests that single-point measurements of $\mathrm{CO}_{2}$ and $\mathrm{H}_{2} \mathrm{O}$ flux may not sufficiently account for the spatial variability of agricultural systems.

\section{Cumulative Carbon Uptake and Water Use}

Results from the daily flux measurements were used to compute seasonal carbon (C) uptake and water use by the corn and soybean vegetation and are presented in Figures $6 \mathrm{a}$ and $6 \mathrm{~b}$. The results represent totals beginning from about mid-June through mid-August 2002 and represent nearly the entire period of biomass accumulation for the crop based on our biomass sampling for this year. This period would not be adequate 

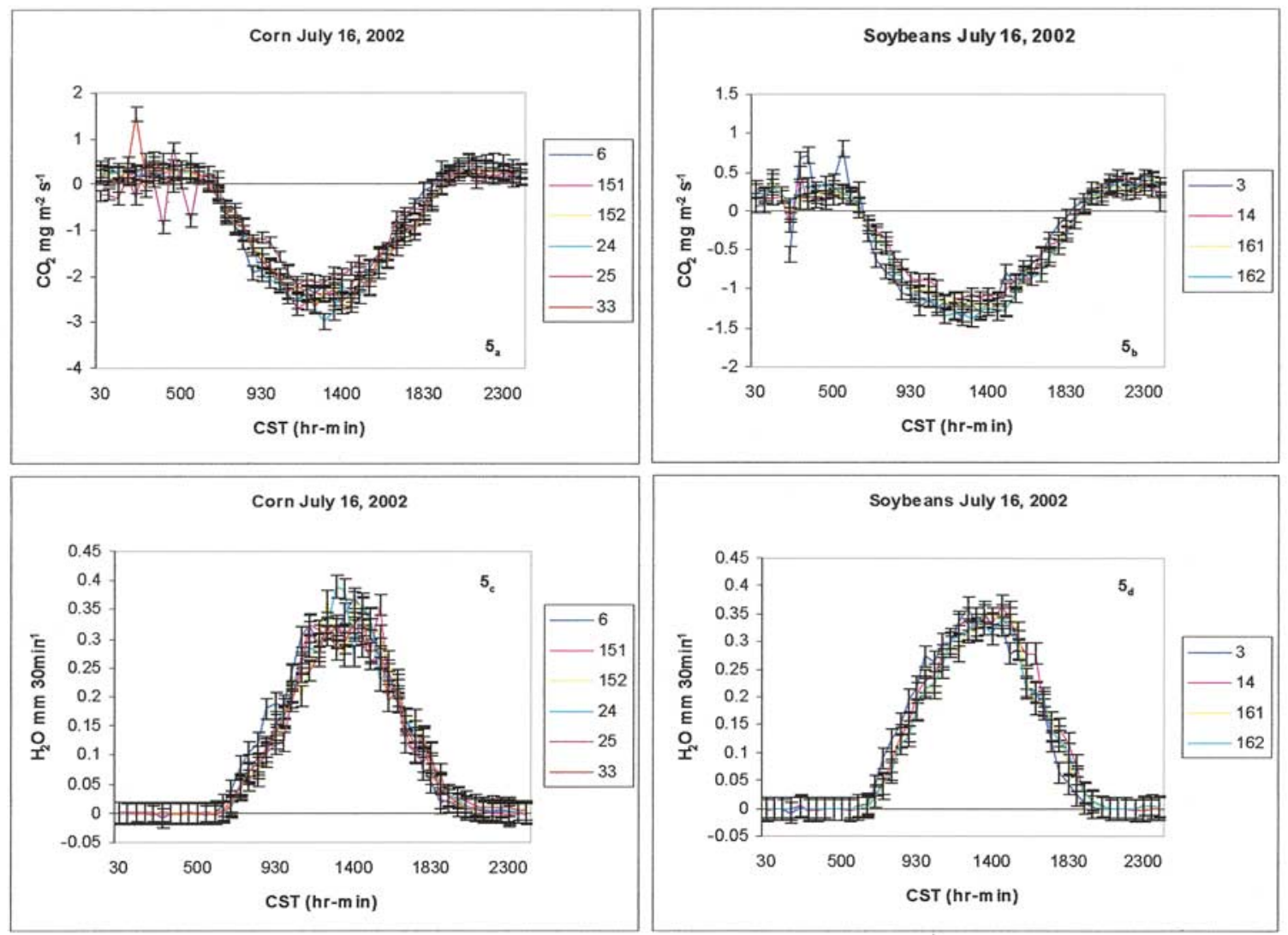

Figure 5. (a) Mean and standard error of $\mathrm{CO}_{2}$ flux data across six corn fields in the WCW on 16 July 2002 (b) Mean and standard error of $\mathrm{CO}_{2}$ flux data across four soybean fields in the WCW on 16 July 2002 (c) Mean and standard error of $\mathrm{H}_{2} \mathrm{O}$ vapor flux data across six corn fields on 16 July, 2002 (d) Mean and standard error of $\mathrm{H}_{2} \mathrm{O}$ vapor flux data across four soybean fields on 16 July 2002.

in other years in which biomass accumulation often extends into late September. The variation observed among the different fields is magnified in the seasonal totals with large differences evident among fields. Two of the soybean fields (161 and 162) had comparable seasonal totals of $\mathrm{C}$, whereas field 03 showed considerably larger totals. A primary difference between fields $161 / 162$ and 03 was the planting method. Fields 161 and 162 were planted with a flex coil method that resulted in a random distribution of the soybean plants, whereas field 03 was planted with a traditional row width of $0.20 \mathrm{~m}$. At this point, it is unclear if the planting method was related to the $\mathrm{C}$ uptake differences. Considerably more variation in $\mathrm{C}$ uptake was observed for corn, where all cornfields were planted with a row spacing of $0.76 \mathrm{~m}$.

Seasonal C uptake for corn nearly doubled that of the soybeans. Carbon uptake values ranged between a low of $\sim 490 \mathrm{~g} / \mathrm{m}^{2}$ to over $650 \mathrm{~g} / \mathrm{m}^{2}$. Soybean uptake values ranged between 200 and $300 \mathrm{~g} / \mathrm{m}^{2}$. The inte- grated total $\mathrm{C}$ values for corn and soybean were less than the estimated total $\mathrm{C}$ in the plant biomass. Typical total aboveground biomass for the corn canopies at maximum leaf area was $\sim 1500 \mathrm{~g} / \mathrm{m}^{2}$, whereas for soybeans, it was about $900 \mathrm{~g} / \mathrm{m}^{2}$ (Hatfield and Prueger 2001). Root biomass was not measured during these experiments, which may be substantial for these crops. If we assume the root biomass to be $\sim 50 \%$ of the total aboveground biomass and the plant biomass to be $45 \%$ C (Mayaki and others 1976), then estimated C accretion in corn was $\sim 1012 \mathrm{~g} \mathrm{C} / \mathrm{m}^{2}$, and in soybeans, it was $540 \mathrm{~g} \mathrm{C}^{2} \mathrm{~m}^{2}$.

Water-use totals (in millimeters) for the corn and soybean sites showed large variations among sites similar to the $\mathrm{CO}_{2}$ fluxes (Figure 6b). The highest water-use totals were by all the corn sites except for field 25, which had the lowest water use of all sites, even for soybeans. This was consistent with the fact that field 25 was planted in a poor (low organic matter) sandy and weed-infested field. Water-use totals ranged between a 
(a)

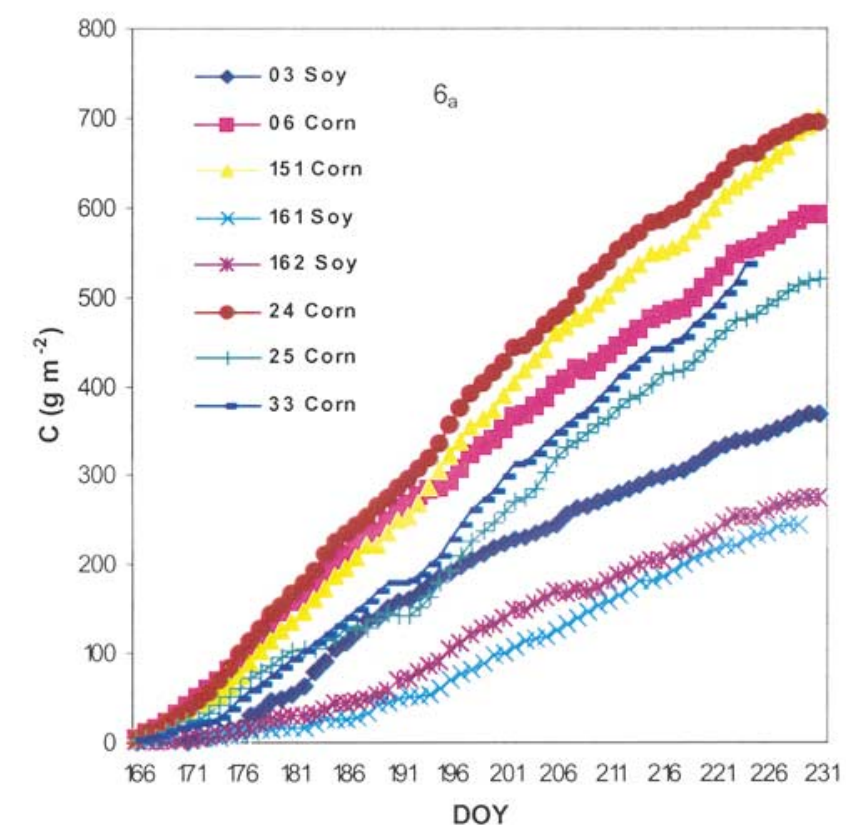

(b)

Figure 6. Cumulative $\mathrm{C}$ (a) and water use (b) for the 2002 growing season for corn and soybeans in the Walnut Creek Watershed.

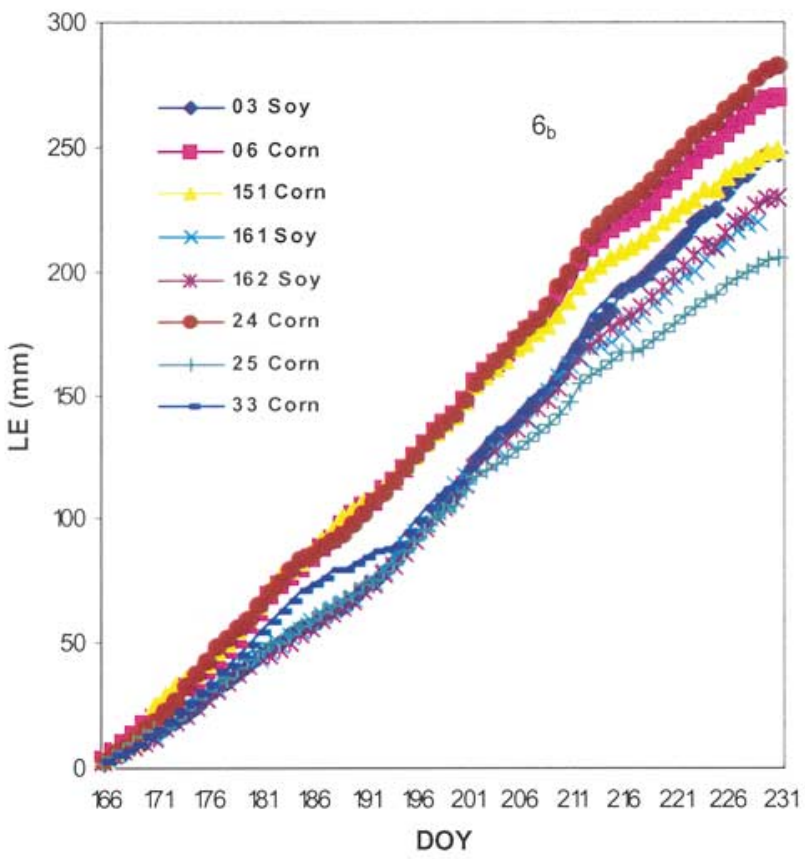

low of just under $200 \mathrm{~mm}$ to a high of over $250 \mathrm{~mm}$ for this portion of the growing season and are typical of the amount of crop water use from past studies in the WCW (Hatfield and Prueger 2001). 


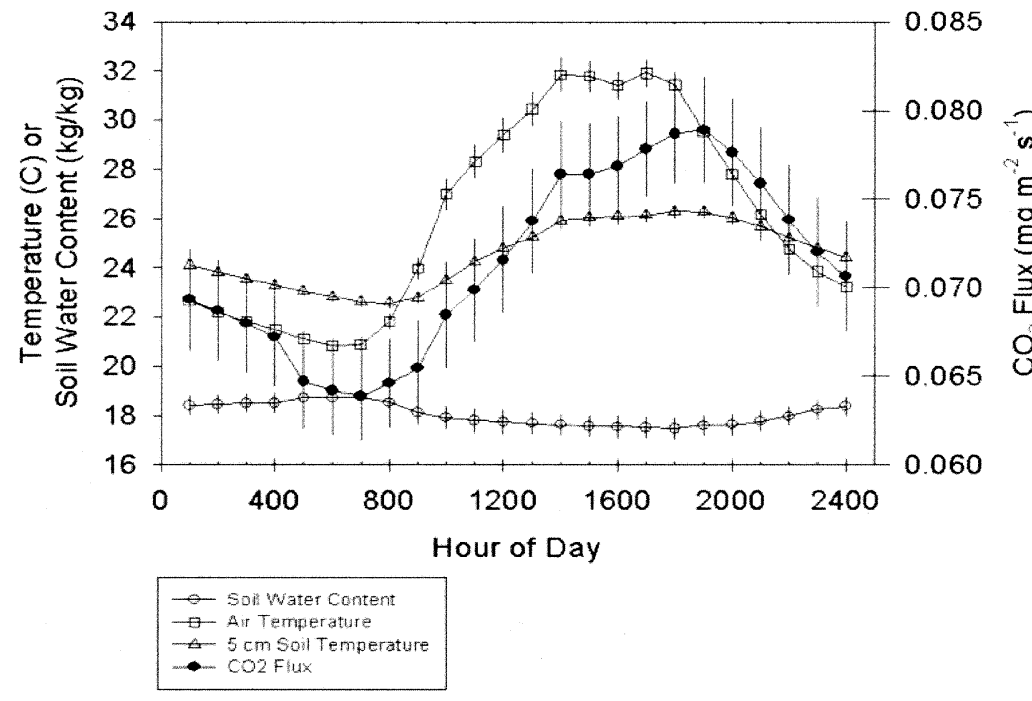

Figure 7. Average diurnal variability of soil + root respiration, temperature, and soil water content from 19 June to 1 August 2002.

\section{Soil $\mathrm{CO}_{2}$ Flux}

Soil + root respiration also exhibited diurnal patterns (Figure 7). Carbon dioxide flux from the soil surface was always positive, with lowest fluxes occurring in the early morning hours and highest fluxes occurring in the late afternoon and early evening. Diurnal variability of soil + root respiration followed the general diurnal temperature fluctuations exhibited by soil temperature. It is important to note that the mean soil + root respiration $\mathrm{CO}_{2}$ fluxes ranged from 0.064 to $0.079 \mathrm{mg} / \mathrm{m}^{2} / \mathrm{s}^{-}$and were substantially less than the nighttime fluxes presented in Figures $4 \mathrm{a}$ and $4 \mathrm{~b}$. However, these results are consistent with our direct assessment of nighttime $\mathrm{CO}_{2}$ partitioning, which indicated that soil + root respiration accounts for only $14 \%$ of the total nighttime flux. Applying this value of $14 \%$ to the measured soil $\mathrm{CO}_{2}$ flux resulted in estimates of nighttime fluxes of $0.45-0.56 \mathrm{mg} / \mathrm{m}^{2} / \mathrm{s}$, which are similar to the fluxes observed in Figures $4 \mathrm{a}$ and $4 \mathrm{~b}$.

Extrapolation of our chamber-based soil $\mathrm{CO}_{2}$ flux measurements made from 19 June to 1 August 2002 over the measurement period represented in Figure 6 yielded an estimate of $\mathrm{CO}_{2}$ derived from soil + root respiration of $128 \mathrm{~g} \mathrm{C} / \mathrm{m}^{2}$, with a corresponding $95 \%$ confidence interval of $40-168 \mathrm{~g} \mathrm{C} / \mathrm{m}^{2}$. Measurement of soil $\mathrm{CO}_{2}$ flux helps to reduce the uncertainty in the $\mathrm{C}$ content in the plant biomass estimates obtained through the atmospheric measurements, as this soilderived $\mathrm{CO}_{2}$ may be incorporated into the growing crop.

\section{Canopy $\mathrm{CO}_{2}$ Profile Concentrations in Corn}

Another source to consider in $\mathrm{C}$ balances for a crop canopy is the recycling of $\mathrm{C}$ released and reused within the canopy volume. We addressed this portion of the $\mathrm{C}$ balance using measured profiles of $\mathrm{CO}_{2}$ and $\mathrm{H}_{2} \mathrm{O}$ vapor within a corn canopy. Measurements (below the canopy) of $\mathrm{CO}_{2} / \mathrm{H}_{2} \mathrm{O}$ density concentrations show strong diurnal oscillations of $\mathrm{CO}_{2}$ enrichment and depletion of the corn canopy airspace. The corn canopy at this time had an LAI of 4.5 with a height of $2.2 \mathrm{~m}$ and was at the early stage of grain filling. $\mathrm{CO}_{2}$ profile results for 4 August 2002 for 4 consecutive hours during nighttime, morning transition (sunrise), and daylight periods reveal large and rapid density changes $\mathrm{CO}_{2} / \mathrm{H}_{2} \mathrm{O}$ within the canopy volume (Figures 8a-8e). Consecutive hourly profiles beginning at $0230 \mathrm{~h}$ until sunrise at about $0530 \mathrm{~h}$ CST show a gradual hourly enrichment of $\mathrm{CO}_{2}$ in the canopy airspace during the 4-h period, with the largest increase $(>100 \mathrm{ppm})$ occurring just before sunrise between the hours of 0430 and 0530 CST (Figure $8 \mathrm{a})$. The increase was coincident with the period of lowest average wind speed $\left(<0.2 \mathrm{~m} / \mathrm{s}^{1}\right)$ occurring between 0430 and $0530 \mathrm{~h}$ during which the replenishment of the canopy airspace from aloft (atmosphere) was at a minimum and least efficient. During this period, the mean wind speed above the canopy was less than $0.5 \mathrm{~m} / \mathrm{s}$ but gradually increased during the early morning hours. The shape of the $\mathrm{CO}_{2}$ profiles within the canopy was partly related to the lack of turbulent exchange within the canopy; however, this phenomenon occurs most nights and is a major source of recycling of $\mathrm{C}$ within the canopy.

Biological respiration processes from the soil and plant contributed to $\mathrm{CO}_{2}$ accumulation in the canopy during the dark hours. This was reflected in the shape of the profile, where lower concentrations of $\mathrm{CO}_{2}$ were found nearest the soil surface $(0.15 \mathrm{~m})$ and then gradually increased with height into the canopy, where the 


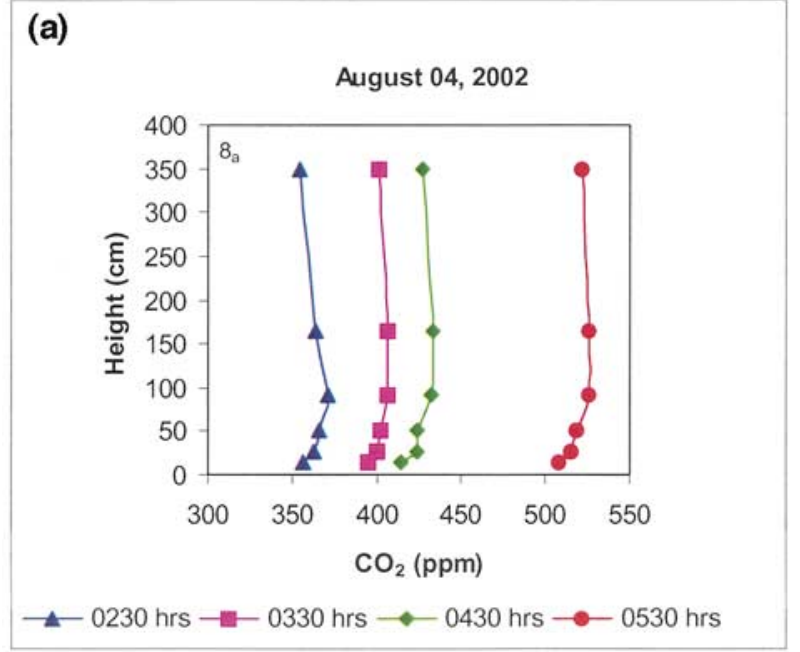

(b)

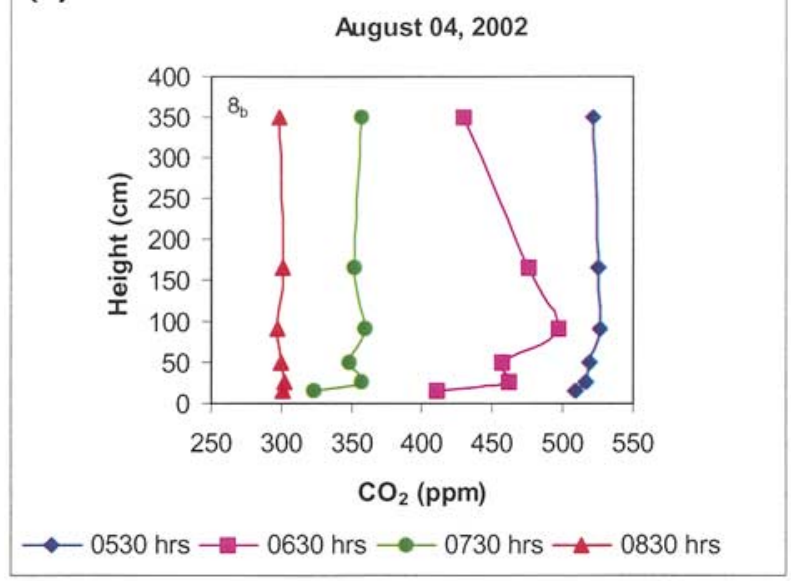

(c)

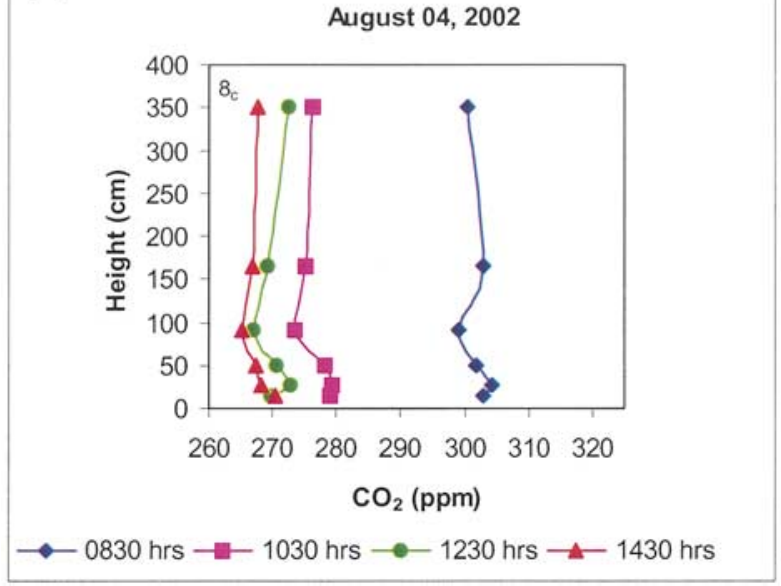

Figure 8. Carbon dioxide concentration profiles for corn from (a) 0230 to $0530 \mathrm{~h} \mathrm{CST,} \mathrm{(b)} \mathrm{from} 0530$ to $0830 \mathrm{~h} \mathrm{CST}$, and (c) 0830 to $1430 \mathrm{~h} \mathrm{CST}$. leaf area density was greater. In addition, canopy architecture near the soil surface $(0.15-0.50 \mathrm{~m})$ contained fewer and smaller leaves and were in early stages of senescence, suggesting lower physiological activity relative to the leaves in the mid to upper portion of the canopy. Profile shapes were slightly skewed to the right (increasing $\mathrm{CO}_{2}$ with height) and were consistent with greater $\mathrm{CO}_{2}$ respiration in the region of higher leaf area density. The shape of the within corn canopy profiles were consistent with those first reported by Lemon and Wright (1969).

The relative contributions of corn leaf/shoot, root, and soil respiration to net nighttime $\mathrm{CO}_{2}$ production were estimated directly using a chamber technique. Large chambers $(166 \mathrm{~L})$ placed directly over corn plants on 2 July 2002 yielded a mean $\mathrm{CO}_{2}$ flux of $1.1 \mathrm{mg}$ $\mathrm{CO}_{2} / \mathrm{m}^{2} / \mathrm{s}$ (std. dev. $=0.59$ ). This value represents the contribution of shoots, roots, and soil. Corn plant shoots were then removed and measurements were repeated at the same locations, yielding a mean $\mathrm{CO}_{2}$ flux of $0.15 \mathrm{mg} \mathrm{CO} 2 / \mathrm{m}^{2} / \mathrm{s}$ (std. dev. $=0.044$ ) that reflected root and soil respiration. Measurement of soil respiration at fallow locations adjacent to the cropped locations exhibited a mean flux of $0.088 \mathrm{mg} \mathrm{CO} 2 / \mathrm{m}^{2} / \mathrm{s}$ (std. dev. $=0.062)$. Using these values to estimate partitioning of nighttime $\mathrm{CO}_{2}$ flux, we estimate that shoots account for $86 \%$ of the production, roots account for $6 \%$, and soil respiration accounts for $8 \%$ of the total $\mathrm{CO}_{2}$ production observed at night.

Above-canopy $\mathrm{CO}_{2}$ concentrations $(3 \mathrm{~m})$ were observed to be slightly lower than those within the canopy. In general, the region with the highest $\mathrm{CO}_{2}$ concentrations was coincident with the region of maximum corn leaf density located at $0.91 \mathrm{~m}$ AGL. During the next $4 \mathrm{~h}$ from 0530 (around sunrise) through $0830 \mathrm{~h} \mathrm{CST}$, there was a cessation of $\mathrm{CO}_{2}$ enrichment and the onset of $\mathrm{CO}_{2}$ depletion in the canopy airspace (Figure 8b). Initially, there was a large and rapid depletion of $\mathrm{CO}_{2}$ concentration between 0530 and $0630 \mathrm{~h}$ CST signaling a significant physiological response of the corn vegetation to incoming solar radiation. Subsequent profiles show continual temporal depletion as more radiation penetrated the canopy with increasing sun angle with a corresponding change in the shape of the profiles. At $0530 \mathrm{~h}$, the profile was well defined with increasing $\mathrm{CO}_{2}$ concentrations with height into the canopy. At $0630 \mathrm{~h}$, the profile became distorted and began to show lower $\mathrm{CO}_{2}$ values with increasing height into the canopy at 0.5 and $1.65 \mathrm{~m}$. The distortion may be interpreted as resulting from the transition between a nighttime enrichment phase to one of depletion in response to increasing solar radiation and air temperature. The following $2 \mathrm{~h} \mathrm{(0730} \mathrm{and} \mathrm{0830)} \mathrm{showed} \mathrm{a} \mathrm{reestablishment} \mathrm{of} \mathrm{the}$ 
canopy profile but now slightly skewed to the left with lower $\mathrm{CO}_{2}$ values, with increasing height into the region of greater leaf density. This was reasonable, as the region of maximum leaf area would also be the region of maximum $\mathrm{CO}_{2}$ uptake. At 0730 and $0830 \mathrm{~h}$, concentration values have clearly been reduced as a function of plant uptake. This was supported by $\mathrm{EC} \mathrm{CO}_{2}$ turbulent flux estimates during the same period as the profile measurements, which showed a net downward direction of $\mathrm{CO}_{2}$ transport from the atmosphere to the canopy. Figure 8c continues the temporal progression of the $\mathrm{CO}_{2}$ concentrations from morning to afternoon hours (0830-1430 h CST). There was a considerable decrease in the $\mathrm{CO}_{2}$ values between the hours of 0830 and 1030 as maximum light saturation and penetration into the canopy was rapidly approached. In addition, the profiles are now well established in response to the plant uptake conditions below the canopy. Carbon dioxide values were considerably below mean global ambient values $(\sim 360 \mathrm{ppm})$ throughout the canopy airspace as well as above the canopy, suggesting that during periods of active plant growth, the corn-soybean surface is clearly a sink for carbon dioxide.

\section{Canopy $\mathrm{H}_{2} \mathrm{O}$ Profile Concentrations in Corn}

Nighttime water vapor profiles showed a steady decrease in water vapor concentration from 0230 to $0530 \mathrm{~h}$ CST (Figure 9a). This was opposite to the $\mathrm{CO}_{2}$ trend observed in Figure 8a and expected, as ET was essentially shutdown during this period. As nighttime progressed, the canopy airspace is continually replenished with drier air from aloft, steadily decreasing the water vapor concentration below the canopy. Profile shapes are well established and nearly linear, which is reasonable, as energy necessary for evaporation or transpiration (ET) is unavailable during this period. Between the hours of 0530 and 0830 , water vapor concentration values gradually increased coincident with $\mathrm{CO}_{2}$ uptake (Figure 9b). This was also expected, as $\mathrm{CO}_{2}$ uptake increase correspond with increased water vapor release from leaf stomata. Profile measurements from 0830 to $1430 \mathrm{~h}$ (Figure 9c) showed that water vapor concentrations continue to increase as the daylight period progressed, reflecting increasing ET from soil and plant sources. During this period, water vapor profiles had a more pronounced shape as a function of height with lower values near the soil surface (significantly lower leaf concentration) and higher values in the canopy space with the most leaf area $(0.91$ and $1.65 \mathrm{~m})$.

There were dynamic and progressive changes in $\mathrm{CO}_{2} / \mathrm{H}_{2} \mathrm{O}$ concentrations within the canopy beginning at sunrise and ending in the late afternoon (Figures 8 and 9). These changes were the result of complex
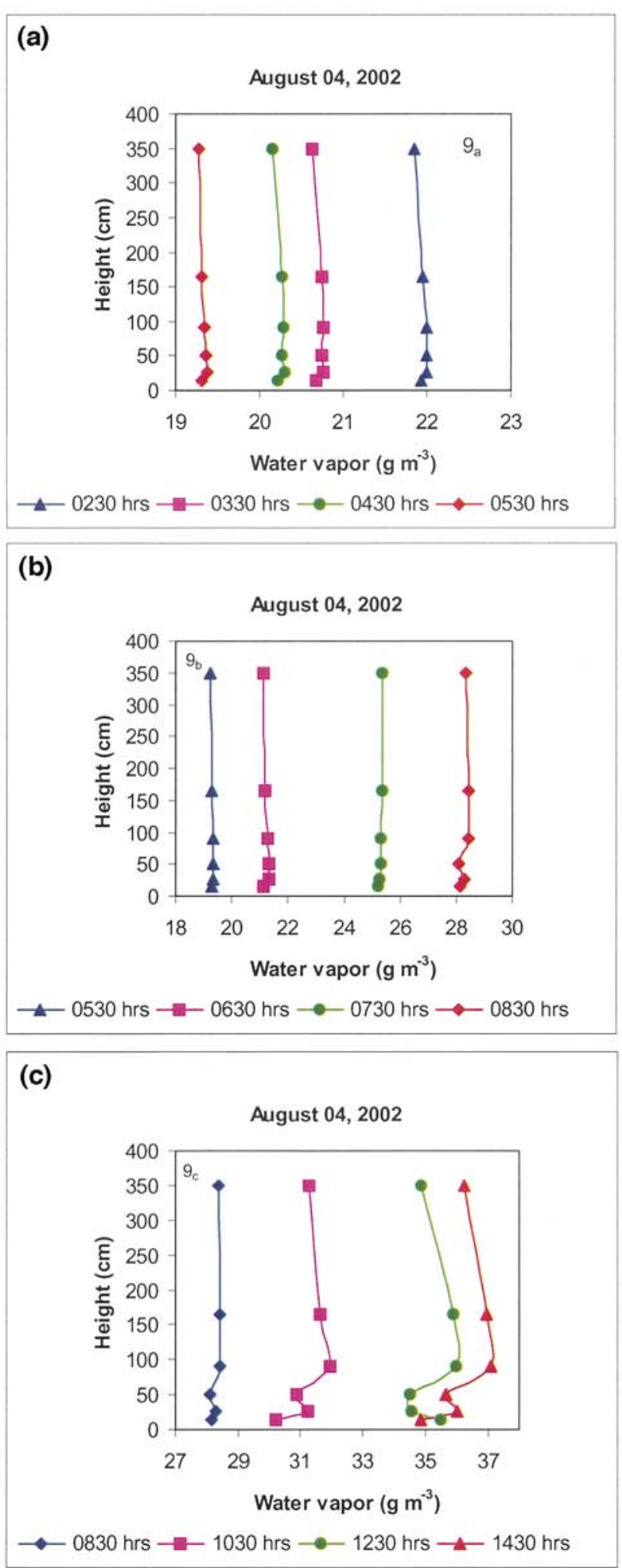

Figure 9. Water vapor concentration profiles for corn from (a) 0230 to $0530 \mathrm{~h} \mathrm{CST,} \mathrm{(b)} \mathrm{from} 0530$ to $0830 \mathrm{~h} \mathrm{CST}$, and (c) from 0830 to $1430 \mathrm{~h} \mathrm{CST}$. 
interactions involving the soil, plant, and boundary layer atmosphere. The concentration dynamics were strongly diurnal and at times represent a well-coupled land-vegetation-atmosphere process.

\section{Conclusions}

Diurnal and seasonal dynamics of $\mathrm{CO}_{2}$ and $\mathrm{H}_{2} \mathrm{O}$ vapor exchange in corn and soybean canopies revealed the dynamic nature and interrelationship of the exchanges in crop canopies. The diurnal changes are affected by the soil water status, stage of crop development, and available energy, whereas seasonal changes are caused by the interaction between the soil type (soil water-holding capacity) and management. The influence of soil type and management practice on $\mathrm{CO}_{2}$ and $\mathrm{H}_{2} \mathrm{O}$ vapor fluxes were detectable using measurement systems positioned above or within the crop canopy. Each of these measurement systems provided a different view of the canopy response, and when coupled with soil respiration measurements, a more complete understanding of the linkages among the crop and soil environment emerged. The discrepancy between the daily integrated $\mathrm{CO}_{2}$ uptake throughout the season and the estimated $\mathrm{C}$ accumulated in the total crop biomass obtained from the destructive canopy measurements raised questions about our understanding of the carbon budget of cropping systems. Advances in instrumentation to quantify the dynamics of $\mathrm{C}$ fluxes from the atmosphere, soil, and plant components of the cropping system allowed for a more complete understanding of these processes. Our measurements clearly demonstrate the dynamic nature of $\mathrm{CO}_{2}$ concentrations within canopies. Within-canopy recycling of $\mathrm{CO}_{2}$ in dense canopies may not be accounted for in the micrometeorological approaches to carbon balance. Our estimates of soil $\mathrm{CO}_{2}$ flux resolved some of the discrepancy between biomass and meteorological approaches. Further resolution of these discrepancies will come through increased understanding of the causes of spatial variation in $\mathrm{CO}_{2}$ flux from soil and matching the spatial scales among the components of the carbon balance (e.g., soil, plant, and atmosphere). Combining soil respiration, within-canopy and above-canopy $\mathrm{CO}_{2}$ and $\mathrm{H}_{2} \mathrm{O}$ vapor fluxes increased the potential to quantify the diurnal and seasonal changes in $\mathrm{C}$ storage across a range of soil types, landscapes, and management systems. This level of detail will improve our understanding of Midwestern cropping systems and their role in the global $\mathrm{C}$ and water cycles. Our results illustrate that even in a well-managed agro-ecosystem with relatively uniform vegetated surfaces, variability in water use and $\mathrm{C}$ uptake are routinely encountered and the magnitude of this variation is quite large within a day across sites and the cumulative effect of these daily differences are compounded when aggregated into seasonal totals. This is to be expected in regions where the source of water is entirely dependent on seasonal rainfall patterns; under these conditions predicting accurate water use and $\mathrm{C}$ uptake for managed ecosystems will be challenging.

\section{Literature Cited}

Allen, L. H. 1971. Variations in carbon dioxide concentration over an agricultural field. Agricultural Meteorology 8:5-24.

Ambus, P., and G. P. Robertson. 1998. Automated near-continuous measurement of carbon dioxide and nitrous oxide fluxes from soil. Soil Science Society of America Journal 62:394-400.

Baldocchi, D. D., S. B. Verma, and N. J. Rosenberg. 1981. Seasonal and diurnal variation in the $\mathrm{CO}_{2}$ flux and $\mathrm{CO}_{2}$-water flux ratio of alfalfa. Agricultural Meteorology 24:175-184.

Berner, R. A. 1997. The rise of plants and their effect on weathering and atmospheric $\mathrm{CO}_{2}$. Science 276:544-546.

Buchmann, N., and J. R. Ehleringer. 1998. $\mathrm{CO}_{2}$ Carbon dioxide concentration profiles, and carbon and oxygen isotopes in $\mathrm{C}_{3}$ and $\mathrm{C}_{4}$ crop canopies. Agricultural and Forest Meteorology 89:45-58.

Buchmann, N., W.-Y. Kao, and J. R. Ehleringer. 1996. Carbon dioxide concentrations with-in forest canopies-Variation with time, stand structure, and vegetation type. Global Change Biology 2:421-432.

Buchmann, N., W. Y. Kao, and J. R. Ehleringer. 1997. Influence of stand structure on carbon-13 of vegetation, soils, and canopy air within deciduous and evergreen forests in Utah (USA). Oecologia 110:109-119.

Hatfield, J. L., and J. H. Prueger. 2001. Increasing nitrogen use efficiency of corn in Midwestern cropping systems. Proceedings of the 2nd International Nitrogen Conference on Science and Policy. The Scientific World 1(S2:682-690.

Hatfield, J. L., D. B. Jaynes, M. R. Burkart, C. A. Cambardella, T. B. Moorman, J. H. Prueger, and M. A. Smith. 1999. Water quality in Walnut Creek Watershed: Setting and farming practices. Journal of Environmental Quality 28:11-24.

Houghton, R. A. 1999. The annual net flux of carbon to the atmosphere from changes in land use 1850-1990. Tellus 51B:298-313.

Houghton, R. A., and J. L. Hackler. 1995. Continental scale estimates of the biotic carbon flux from land cover change: 1850-1980. Report No. ORNL/CDIAC-79, NDP-050. Oak Ridge National Laboratory, Oak Ridge, Tennessee 144 pp.

Hutchison, G. L., and A. R. Mosier. 1981. Improved soil cover method for field measurement of nitrous oxide fluxes. Soil Science Society of America Journal 45:311-316.

Inoue, H. Y., and H. Matsueda. 2001. Measurements of atmospheric $\mathrm{CO}_{2}$ from a meteorological tower in Tsukuba, Japan. Tellus 53B:205-219.

Kasting, J. F. 1993. Earth's early atmosphere. Science 259:920-926. 
Keeling, C. D. 1961. The concentration and isotopic abundances of atmospheric carbon dioxide in rural areas. Geochimica et Cosmochimica Acta 24:277-298.

Keeling, C. D., T. P. Whorf, M. Whalen, and J. van der Pilcht. 1995. Interannual extremes in the rate of rise of atmospheric carbon dioxide since 1980. Nature 381:218-221.

Kustas, W. P., Prueger, J. H., Hatfield,J. L.MacPhersonJ. I.WoldeM.Neale, C. M. U. Eichinger, W. E. Cooper, D. I. Norman, J. M. and Anderson. M. 2003. An overview of the soil-moisture-atmospheric-coupling-experiment (SMACEX) in central Iowa. Pages 1-5 in American Meteorological Society, 17th Conference on Hydrology, February 9-12, 2003, Long Beach, CA.

Lemon, E. R. 1960. Photosynthesis under field conditions: II. An aerodynamic method for determining the turbulent carbon dioxide exchange between the atmosphere and a cornfield. Agronomy Journal 52:697-703.

Lemon, E. R., and J. L. Wright. 1969. Photosynthesis under field conditions. XA. Assessing sources and sinks of carbon dioxide in a corn (Zea mays L.) crop using a momentum balance approach. Agronomy Journal 61:405-413.
Mayaki, W. C., L. R. Stone, and I. D. Teare. 1976. Irrigated and non-irrigated soybeans, corn and grain sorghum root systems. Agronomy Journal 68:532-534.

McNaughton, K.G. (1989) Regional interactions between canopies and atmosphere in: Plant canopies: Their growth form and function (eds) Russel, G., Marshall, B., Jarvis, P.J., Cambridge University Press, Cambridge, UK, pp 63-81.

Rayner, P., I. Enting, R. Francey, and R. Lagenfelds. 1999. Reconstructing the recent carbon cycle from atmospheric $\mathrm{CO}_{2}, \delta^{13} \mathrm{C}$ and $\mathrm{O}_{2} \mathrm{~N}_{2}$ observations. Tellus 51B:213-232.

Reicosky, D. C. 1989. Diurnal and seasonal trends in carbon dioxide concentrations in corn and soybean canopies as affected by tillage and irrigation. Agricultural and Forest Meteorology 48:285-303.

Tans, P. P., I. Y. Fung, and T. Takahashi. 1990. Observational constraints on the global atmospheric $\mathrm{CO}_{2}$ budget. Science 247:1431-1438.

Wright, J. L., and E. R. Lemon. 1966. Photosynthesis under field conditions. IX. Vertical distribution of photosynthesis within a corn crop. Agronomy Journal 58:265-268. 